\title{
An Evolutionary Model for the Neoproterozoic (Ediacaran)-Phanerozoic Biosphere. Part One: Concepts and Exploitation of Aquatic Environments
}

\author{
Andrian Vasilievich Popovi, Galina Petrovna Nestell ${ }^{2}$, Merlynd Keith Nestell², \\ Walter Leroy Manger ${ }^{3}$ \\ ${ }^{1}$ Institute of Earth Sciences, St. Petersburg State University, Saint Petersburg, Russia \\ ${ }^{2}$ Department of Earth and Environmental Sciences, University of Texas at Arlington, Arlington, TX, USA \\ ${ }^{3}$ Department of Geosciences, University of Arkansas, Fayetteville, AR, USA \\ Email: popov@ap1250.spb.edu,gnestell@uta.edu,nestell@uta.edu,wmanger@uark.edu
}

How to cite this paper: Popov, A.V., Nestell, G.P., Nestell, M.K. and Manger, W.L. (2017) An Evolutionary Model for the Neoproterozoic (Ediacaran)-Phanerozoic Biosphere. Part One: Concepts and Exploitation of Aquatic Environments. Open Journal of Geology, 7, 1386-1403.

https://doi.org/10.4236/ojg.2017.79092

Received: July 27, 2017

Accepted: September 16, 2017

Published: September 19, 2017

Copyright $\odot 2017$ by authors and Scientific Research Publishing Inc. This work is licensed under the Creative Commons Attribution International License (CC BY 4.0).

http://creativecommons.org/licenses/by/4.0/

\begin{abstract}
The evolutionary history of the biosphere is characterized by aromorphosis. biological evolution by a general increase in the degree of organization without developing high degrees of specialization [1]. Four major stages of the evolutionary transformation of life (mega-aromorphoses) can be established in the recorded succession of the Neoproterozoic (Ediacaran)-Phanerozoic aromorphoses reflecting changes of the dominant groups. They are defined by the appearance of archetypes ensuring the possibilities of a prolonged and diverse rise of the level of their organization leading to significant increase in the activity of living organisms and their emerging independence from the environment. A successive series of developmental stages exploiting of the aquatic environment of the Neoproterozoic (Ediacaran)-Phanerozoic biosphere can be established based on their dominant groups: the biospheres of protozoans, proto-metazoans, protobilaterals, fishes and amphibians.
\end{abstract}

\section{Keywords}

Biosphere, Super-Aromorphoses, Mega-Aromorphoses, Archetype

\section{Introduction}

\subsection{Microevolution and Macroevolution}

Progressive changes in size, shape, system function, and other observable physical and biochemical characteristics that occur during the life of an organism are 
translated into mature systems functioning as the phenotype, and through reproduction, they are preserved in the genetic makeup of an organism or group of organisms that eventually becomes the genotype. The genotype comprises the genetic makeup of an organism, while the phenotype combines genetic and environmental influences that have come together to create that organism's physical appearance and behavior. Vernadsky noted that activity and aggressiveness of living organisms finds its strongest expression in reproduction [2]. Darwin recognized that reproduction drives the evolution of all living matter [3]. Through evolutionary development and successful reproduction, organisms have been able to fill, and in some cases, over-fill, the entire available habitable space on earth.

The most important characteristic of organisms that drives their phenotypic and genotypic changes is the short duration of their individual existences, and the potential for elimination of the group to which they belong by competition with other organisms. These factors also apply to biosystems of higher rank. The unique combination of the specific biosystem characteristics is the basis for natural selection, and the cause of rapid evolution. The direction of the evolutionary change reflects the success and increasing independence of the developing living systems and their accommodation by the biosphere.

Evolutionary successes frequently signify that the changes in one group of organisms will likely influence the evolutionary development of another group or groups. Thus, a biological system can be formed from an opposite, but positive, connection. This process becomes a fundamental natural law-adaptation to an external environment begins clearly as an internal process responding to strong competitive pressure within a particular group of organisms, but becomes an external process of change as other groups of organisms become involved. Thus, initial internal change within a group of organisms causes later external change.

A fundamental characteristic of both organisms and biosystems is the success of their evolutionary transformations in response to the influence of both internal and external factors; evolutionary changes always have some adaptive significance. Evolutionary reconstruction can be achieved through the smallest changes in biosystem structure. This "economy of scale" is a fundamental characteristic of life on earth. Principal differences exist in the reaction of an organism to the pressure of abiotic versus biotic influences. Evolutionary transformations in an organism that have been induced by abiotic forces are in reality the recovery from disequilibrium between that organism and its environment. In this case, the process is completed and additional changes are not required, because there is no stimulus for further evolutionary change. Evolutionary reaction to biotic factors, a significantly different process, reflects the advantage of one group of organisms over other groups. The reaction to biotic factors also disrupts the equilibrium of the organism with its environment, and inevitably prompts a corresponding reaction of the biological characters possessed by all living matter. Thus, an unbalanced condition is preserved that constrains the continuity of the evolutionary process [4] [5] [6] [7]. 
There is a fundamental dissimilarity in the quality of evolutionary transformations under the influence of biotic factors, in contrast to the influence of abiotic factors. The influence of biotic factors is especially clear in the stimulation of the development of integrated mechanisms of an organism related to the rise of the activity level within biosystems. The improvement of such adaptations can be accompanied by the reconstruction of the entire structure of an organism requiring a prolonged and directed selection pressure that can be created only by biotic factors. The tremendous qualitative progress reached by living organisms ranging from protozoans to humans cannot be explained by the influence of, and response to, harsh physical-chemical conditions. Abiotic agents of the external environment, in principal, cannot be a leading factor in the evolutionary process that would stimulate the continuous progressive development of biological systems. The nature of the qualitative influence of abiotic factors of the external environment cannot promote the progressive evolution of organisms that is connected with the deep and extensive reconstructions of their structure.

Adaptation to the abiotic environment is accomplished through the competition among organisms and other biosystems. The Earth possesses three main environmental settings: aquatic, terrestrial, and atmospheric. The adaptation to each setting significantly influences the peculiarities of the organisms producing aqua-archetype, terra-archetype and aerial-archetype structures respectively. Adaptations to the abiotic environment provide additional opportunities for competition among its organisms [4] [5] [6] [7]. Thus, two main directions may be distinguished in the general pattern of the evolutionary transformations. One reflects the influence of external abiotic conditions, whereas the other is driven by internal influences.

Microevolution within a species generates an incremental evolutionary shift that originates almost instantaneously, when compared with the length of geologic time. This initial evolutionary shift serves as the primary basis for macroevolution that proceeds across a significantly greater time interval. Macroevolution selects the most successful archetypes from the myriad of accidental and short-lived genetic combinations originating through reproduction in the process of microevolution under the rigid control of the genotype. Macroevolutionary time intervals provide unlimited opportunities for the testing of quite different variants in the development of phylogenetic groups. The freedom for the interaction of all varieties of biological structures among themselves is the evolutionary principal "all with all" that guaranties greatly diverse possibilities for the realization of macroevolutionary transformations predetermined by the origin of the noosphere [4] [5] [6] [7]. The noosphere, literally mind-sphere, is a postulated sphere or stage of evolutionary development dominated by consciousness, the mind, and interpersonal relationships, jointly coined in Paris, 1926 by the French philosopher, and student of Henri Bergson, Édouard Le Roy, the Jesuit paleontologist Pierre Teilhard de Chardin, and the Russian geochemist, Vladimir Vernadsky. 


\subsection{Evolution and Systematics}

Formally or informally, it is recognized presently that the rank of any taxonomic category corresponds to the quantity of the evolutionary transformations that it has experienced over the course of its existence, i.e., systematics must accurately reflect the peculiarities of phylogenesis. No higher taxa at the level of Division or Phylum originated after the Vendian-Cambrian mega-aromorphosis, but life underwent great qualitative evolutionary changes toward the human condition in the following interval of time.

The study of global evolutionary processes occurring in the biosphere requires documentation of the general quantitative changes of taxa from all phylogenetic groups without regard to their differences. Statistical analysis generally examines smaller taxonomic groupings, such as species and genera, but the value of their qualitative differences is not always appreciated for taxa of the same rank that belong to different groups. Recognition of the discrepancy of the qualitative characteristics of the taxa of the same level, but from different phylogenetic groups, can be of great value in understanding their evolutionary history.

The major groups of animal life developed within the framework reflected by the systematics of their taxonomic categories, apparently without having experienced significant experimentation, at least with evidence that has been preserved. Consequently, systematics does not contradict the presumed evolutionary process. However, within this general and slowly evolving pattern, there can be different directions and rates of evolutionary development. For example, whereas representatives of protozoans, coelenterates, brachiopods and mollusks, except for the coleoids, developed along single lines through the Phanerozoic, at the same time, representatives of the chordates exhibited tremendous changes in their development, culminating in humans. The representatives of the chordates through time are difficult to fit into a coherent framework to which the principals of systematics can be applied. For higher taxa experiencing such progressive evolution, the development of new and innovative structures reflects the appearance and development of a nervous system, particularly a brain. The traditional approach to systematics does not take into account these specific features of evolution [8]. A true picture of the evolution involving all phyla, and the entire biosphere, requires the inclusion and treatment of all characteristics and systems, not just those producing preserved morphological features [8].

\subsection{Structure of the Evolutionary Process}

The evolution of the biosphere is principally understood through its component taxa-the major and long-lived phyla reflecting the successful structure of their archetype, particularly the principle role played by the chordates and other vertebrates [5] [6]. Successful protection from competition is characteristic of their component groups, expressed initially by an increase in the organization of the individual organisms anticipating the appearance of humans and the noosphere.

Organizationally, the great evolutionary transformations that initiated the be- 
ginning of dominant groups were established by super-aromorphoses. These transitions become the main steps in the increase of the organizational level by the progressive evolutionary groups that ultimately influenced the general development of the biosphere. Abundant paleontological material provides the opportunity to organize and describe the details of the evolution of vertebrate groups, and their competitive interactions within the framework produced by super-aromorphoses.

Dominant biological groups force out others, leaving less successfully developed, depressed groups (e.g., arthropods, mollusks, and brachiopods), that are unable to follow the path to further progressive development. These relationships create the basis for the structure of the biosphere [5] [6]. Many groups with limited development do not experience a significant rise in their organizational level during their evolution, and may be described as developing in a single "plane". Protozoans, coelenterates, echinoderms, graptolites and most mollusks represent such groups. Typically, the main direction of their evolutionary development has been in the improvement of their passive defense mechanisms, such as the appearance of different types of shells, carapaces and other similar external structures that provide passive protection. As a consequence, those same groups decreased development of their respective nervous systems and producing limited mobility, or a completely sessile mode of life. Although these phyla have flourished over long ranges, they have been forced out of the "economy of scale" zones of the biosphere, and have lost their ability for further progressive development.

The appearance of a dominant group with an archetype possessing the potential for occupancy of a main biotope challenges the general biospheric construction, which lags slightly behind that of the aromorphosis for that group. The resulting reconstruction reflects a wide adaptive radiation of the dominant group leading to the exchange, suppression and forcing out less successful evolutionary groups from the main biotopes of the biosphere. The sharpest conflict for possession of the main biotopes in the biosphere occurs between previous and newly dominant groups. Less dominant groups occupy the lower levels in the economy of the biosphere and, when adapted to this position, are usually less subject to changes: they have developed almost in a single plane.

In the evolution of the dominant archetypes, the main features of their unlimited evolutionary progress and potential are reflected by the main developmental stages of the structure of the organism. This evolutionary progression began with an improvement of functional morphological adaptations of the organism, and later by the appearance and development of a quantitatively new organ-the brain-that regulates the functions of the organism through the interaction of the informative processes, a completely new phenomenon. Improvements to the brain, its connected central nervous system, and its telereceptors produced a sharp increase in the intensity of reaction and interaction of the organism to its external environment. This development determined the general tendencies of the evolution for living organisms, and characterizes what has 
been called the cerebral stage of the development [4] [5] [6] [7].

The evolutionary movement of the biosphere can be thought of as comprising two layers-an upper one is represented by a stream of the progressive evolutionary characteristics for vertebrates, whereas a lower one encompasses numerous groups of invertebrates that have experienced development in a single plane. The upper biospheric layer of progressive evolution is divided further into two well differentiated sublayers: aquatic vertebrates, assigned to the lower layer, and tetrapods, occupying the upper layer. These layers reflect sharply different, but connected, living conditions in the hydrosphere (aquatic), and terra-biosphere (terrestrial). Land-dwelling vertebrates have developed the highest levels of organization leading to the appearance of new groups of animals with completely new archetypes. Yet, these groups of vertebrates are accommodated within a single subphylum. Considering the basic environmental differences of the hydro- and terra-biospheres, the evolution of these vertebrates should be examined separately to investigate the evolutionary interactions of their representative taxonomic groups.

The biosphere can be divided into evolutionary stages, named for their dominant group: biospheres of protozoans, protometazoans, protobilaterals, fishes, amphibians, reptiles, mammals and birds, culminating in the noosphere. The Vendian-Phanerozoic aromorphoses reflect a change of their dominant groups demonstrating four major steps in the evolutionary transformations of life (mega-aromorphoses). Each of these steps is defined by the appearance of archetypes that provided opportunities for prolonged and variable increases in the organizational level of the body that led to significantly increased activity of life and increasing independence from the environmental control.

Following mega-aromorphoses initially exploited the aquatic environment of the Neoproterozoic (Ediacaran)-Phanerozoic biosphere:

1) Ediacaran (Vendian) mega-aromorphosis-appearance of metazoans possessing a reservoir digestive system and a mouth, followed by the rise of the first soft-bodied protobilaterals distributed through the biosphere of protometazoans (Vendian).

2) Cambrian mega-aromorphosis-domination of skeletal protobilaterals, encompassing the biosphere of protobilaterals (Cambrian and Ordovician).

3) Silurian (Cerebral) mega-aromorphosis-successive domination of endoskeletal bilaterals that possessed a brain (fishes and tetrapods). The influence of this mega-aromorphosis is distributed over the biosphere of fishes, amphibians ( $\mathrm{Si}$ lurian, Devonian, Carboniferous).

\section{Stages in the Development of Biosphere}

\subsection{Ediacaran Mega-Aromorphosis. Biosphere of Protometazoans}

The origin and development of protometazoans is inseparably connected with the hydrosphere as the most favorable medium for the origin and development of very diverse life forms, especially in their earliest stages of evolution. Abiotic 
conditions of the hydrosphere on the Earth reflect an extremely narrow physical-chemical framework controlling the existence of an aquatic environment. The origin and continuous presence of the hydrosphere on the Earth comprised a very long interval of geological time, and provided a medium of weightlessness that simplified the development of biotechnical and physiological systems among developing biota. The hydrosphere also provided a favorable temperature regime in the range of some tens of degrees centigrade above zero that was distributed continuously across most of the earth, a "universal ocean" that contained the essential and indispensable environmental components for the development of organisms, but its characteristics made the hydrosphere a "hothouse" for other biosystems. The early hydrosphere significantly reduced the sharp and unfavorable impacts from abiotic factors, and the presence of its currents promoted dispersion of the developing organisms.

The two main streams of life, plants and animals, had been developed by the beginning of the Phanerozoic. These groups of organisms united to become a single "power system" that formed the fundamental basis for energy exchange in the biosphere. Plants supply animals with food and oxygen; plants receive carbon dioxide from the animals. Animals can use already formed organic substances as a food source: vegetable tissue and tissue of other animals, and also have an intimate dependence on the plants that forms the basis of the food pyramid. These main, but not unique, biospheric dependences guided the development of more complex forms of life already by the beginning of the Phanerozoic [4] [5] [6] [7].

Protometazoans with a gastral cavity and a mouth characterize the Vendian biosphere. The appearance of those features signaled the appearance of extracellular digestion that significantly expanded the ability of organisms to actively influence their external environment. Organisms with diverse bilateral architecture appeared during the Late Ediacaran indicating active motion, an aggressive hunt for food, and defense. The Ediacaran bilaterals represent the initial stage of the aromorphosis of this progressive group.

\subsection{Cambrian Mega-Aromorphosis. Biosphere of Protobilaterals}

Two evolutionary divisions appear almost immediately among the emerging bilaterals. One division was represented by bilaterals that improved their external, plated skeletons, whereas the other division developed and improved its internal skeleton. The appearance of external or internal skeletons was prompted by the necessity for further increase of the activity level of the organism, especially for bilateral ones. The development of a skeletal structure is the key to strong, fast and independent movement, and also provides defense, particularly with possession of a carapace [5] [6] [7]. The earliest and simplest way of forming a skeleton that is connected with the ectoderm is through formation of external hard plates, simultaneously solving the problems of defense and point of support. The earliest, unequivocal step in exoskeletal evolution occurred in the Early Cambrian with the appearance of trilobites and later in the Middle Cambrian with the ap- 
pearance of the europteridians in the Burgess Shale. Whereas the appearance of an external skeleton was not connected with the significant reconstruction of the archetype, it closed the possibility of further progressive development by limiting the opportunity for the additional evolutionary transformations.

Primitive chordates with internal skeletons also appear in the Middle Cambrian Burgess Shale. Pikaia, a protochordate, at one time thought to be the oldest fish, probably had a protonotochord, but certainly the associated genus Metaspriggina, possibly transitional between cephalochordates and the earliest vertebrates, had a notochord as did the later genera Haikouella, Haikouichthys, and Myllokunmingia, although these primitive vertebrates were likely not yet "true" fish. By the Ordovician, however, many species of jawless, agnathan fish had notochords attached to bony skeletal elements, whereas more advanced fish, such as the ostracoderms and placoderms, did not have attached skeletal elements. A complete internal vertebrate skeleton was produced by fish during the Late Ordovician-Silurian. This endoskeletal direction of evolution characterizes all later vertebrates. The development of the internal skeleton is connected with the reconstructions of the archetype, slow at its initial stages, later connected to the acquisition of new adaptations that provided progressive development [4] [5] [6].

The necessity of rapid, purposeful, coordinated movement and motion in space is connected inevitability to the formation and improvement of such adaptations as diverse telereceptors that allow precise orientation in space and, of course, the development of a nervous system responsible for the coordinated actions of all the structures of the organism. The movement of the organism in space requires necessary planning of its actions that presumes the formation of a corresponding organ-the brain.

\subsection{Arthropoda}

Arthropods are possibly represented in the Precambrian Ediacaran faunal assemblage by Spriggina, whose affinities are currently unknown, but have been variously classified as an annelid worm, a rangeomorph-like frond, a protoarticulate, and/or an arthropod, perhaps related to the trilobites. Unquestioned arthropods become abundant by the Middle Cambrian, and are now the most numerous group of organisms on earth, having undergone an extremely complicated and peculiar history of development. From their beginning, the arthropods followed the path of development of the bilateral archetypes that predetermined their progression. At the same time, the presence of external defensive plates and various types of carapaces limited the evolutionary transformations potentially available to the group, especially adaptations of general functions at the progressive levels of development that remain characteristic for living arthropods. For example, the central nervous system has remained basically unchanged through the entire range of the phylum.

Among the arthropods resulting from the Ediacaran-Cambrian mega-aromorphosis, the trilobites became the dominant and progressive group through most of the 
Paleozoic, particularly evolving their increasing mobility [5]. Dogel noted the extreme primitiveness of head appendages and their similarity to thoraxic appendages [9]. The main joint of every head appendage on the internal side had a conical chewing outgrowth, but the trilobites were deprived of a true jaw apparatus [9]. Instead, these outgrowths were turned toward each other and served for capturing and crushing of food [9]. The last two pairs of head appendages may have the appearance of jaws-claws in some species of trilobites [10]. It should be noted that the structure of the appendages is only known for 19 out of the 20,000 described species of trilobites [11]. It is likely that species possessing appendages with claws occurred in large numbers. The dominance of the trilobites continued throughout the Cambrian and Ordovician, after which their diversity and numbers sharply decreased along with their physical size, until they finally disappeared at the end of the Permian.

Eurypteroids were active, predaceous, benthonic animals occupying all aquatic environments and commonly reached a size of $10-20 \mathrm{~cm}$ [12], although giant forms of two or more meters in length are known [13]. Eurypteroids had claw-shaped chelicerae that served for catching and crushing prey, and several pairs of oar-shaped appendages served for swimming. They range from Ordovician to Permian; however, they were most abundant in the Silurian-Devonian. The coincidence of the decrease of trilobite taxonomic diversity with the increase in eurypteroid abundance can be considered as some confirmation of the competitive struggle between these two groups that may have forced the trilobites out from their biological niches [9]. The Eurypteroidea, by acquiring chelicerae, adaptations for quick swimming, and higher development of the proto-brain transitioned to an active mode of life, and thus, achieved a significant advantage compared with trilobites. However, the trilobites had additional competition from the Agnatha, the jawless fish that underwent a diverse expansion in the Silurian and Devonian. This group was very similar to trilobites in their mode of feeding and significantly exceeded the trilobites in level of organization and activity.

The branchiopods, crustaceans reflecting the progressive direction of the development of the arthropods, occupied first place among arthropods by the end of the Paleozoic Era (Carboniferous and Permian). The Malacostraca, advanced eucrustaceans, exhibit an even higher level of the development. The representatives of many lower crustaceans followed a path of narrow specialization, with an attached mode of life and intensification of protective structures, including extra carapaces, such as bivalve shells or carbonate plates, formed by members of both the Branchiopoda and Ostracoda. These groups are extant, but have not experienced further significant evolutionary change since the Paleozoic.

Advanced crustaceans, crabs, crayfish, lobsters and others, are significant isolated groups that developed an active mode of life and inhabit both freshwater, and marine settings from littoral to abyssal depth. The aeucarids and hoplocarids have achieved a higher level of development through the perfection of a 
proto-brain. If the nervous system of the lower crustaceans still reflects that of the annelids (paired brain, peripharynx connectives and a pair of ventral nerve trunks), then the result of the concentration of the nervous system in crabs is represented by two nerve masses. The level of organization of the proto-brain is demonstrated by the behavior of the hermit crab (Pagurus bernhardus), which lives symbiotically with sea anemones. With growth and movement into a larger shell, this hermit crab uses its claws to transfer the sea anemone from its previous shell to the new one [9] [14].

By comparison of the main features of the development of basic arthropod groups, such as trilobites, chelicerates and crustaceans, Dogel proposed distinguishing at least two major phylogenetic branches that had separated phylogenetically very early in arthropod evolution: Mandibulata (Branchiata-racheata) and Amandibulata (Trilobitomorpha-Chelicerata) [9]. The origin of the jaw apparatus in the Mandibulata influenced the formation of a proto-brain, especially the part of it responsible for the formation of associative structures [15]. In contrast, the absence of a true jaw apparatus in trilobites and chelicerates, and the transfer of such important functions connected with feeding to the head appendages of these groups made the formation of the associative apparatus of the proto-brain difficult.

The great significance of the jaw apparatus and the distinguishing characteristics of the development of the brain are apparently general regulators of the evolutionary process. This relationship is confirmed clearly by an analogous situation in the phylogeny of vertebrates, where jawless vertebrates appeared first, yet later lost their place in vertebrate development and dominance to the gnathostomes.

\subsection{Cephalopoda}

In contrast to the main groups of mollusks, which are characterized by extremely primitive structures that developed in one plane through the entire Phanerozoic, the cephalopods are distinguished noticeably by their more progressive directions of development accompanied by higher rates of evolution. Typical evolutionary transformations for the cephalopods, defined by the quick increase in their level of organization, were connected by accomplishment of active movement in space, and the development of a nervous system, including a brain. Improvement of these two adaptations is intimately connected, and defines the general direction of progressive cephalopod evolution. However, the presence of an external shell in many groups of cephalopods, as in most other mollusks, greatly limited their evolutionary development.

The activity level of cephalopods is related to increasing the strength and buoyancy of their shells, which is reflected in the development and change of the suture line, the contact of the septum with the shell wall, and by the shape of the shell itself, which are both connected. In most nautiloids with either a straight or coiled shell, the sutural line is nearly straight. Coiled forms with a discoidal or rounded-compressed, evolute shell often are more complicated with moderately, 
but distinctly subdivided, sutural lines [16]. In coiled shells of the same genus, different species can be distinguished by the depth of the lobes in the sutural lines [16]. For the nautiloids, the evolutionary transformation of the shape of their lobate sutures, is related only to the mechanical strengthening of their shell.

An outstanding feature of cephalopod phylogeny the origin in the Devonian of two major phylogenetic branches: the Ammonoidea and Endocochlia. They improve the hereditary apparatus by allowing more precise and reliable passing of features. This ability significantly expanded the possibilities of the construction of complex evolutionary adaptations, especially in the nervous system. Indeed the appearance of an improved hereditary apparatus allowed these groups to reach a high level of the evolutionary development.

For ammonoids, the stability of the overall shape of their complex lobate sutures, a secondary feature in the system of the ontogenesis of the individual, made a significant contribution to the evolutionary relationships of the component structures of the organism, and demonstrated the improved mechanism for passage of the features of hereditary within the ammonoids [17]. The improved mechanism for passage of hereditary allows a more precise exploitation of favorable evolutionary changes, and also retention of older successful adaptations. Yet, the presence of an external skeleton with limited variability, in this case an external, usually coiled shell, also limits the appearance of more precise production of features reflecting evolutionary transformation.

There are many hypotheses about the role of the sutural line in the phylogeny of ammonoids [17]. Although, most specialists view sutural evolution of the group as highly significant, in the absence of evidence that shell shape directly influences the sutural line (or vice versa), some investigators (i.e., Shindewolf) concluded that there is complete independence of the development of the sutural line in its main characters from the variability of the general development of the shell [17].

During the more than 300 million year development of the ammonoids, additional functions were likely added to the basic role of the septum to further improve the mechanical strengthening of the shell. Each of these new roles for the septum and its suture line had specific characteristics, and likely altered its other functions, but there is no consensus as to the exact significance of the variations in ammonoid suture lines. This uncertainty reflects the lack of understanding of the function of the sutural line in the ammonoid phylogeny. The problem is the result of an incorrect methodical approach that attempts to reveal the evolutionary significance of the sutural line directly, but considers only its importance ontogenetically. Thus, a greater importance is assigned to the sutural line in the organization of the organism than may have actually existed. The evolutionary transformation of the organism creates a special system of strong correlations in which the level of the evolutionary significance of one or another component of the organism in the phylogeny can be different than its actual functional role in ontogeny [17]. 
Initially, the evolutionary complication of the sutural line must have provided mechanical strengthening of the shell. Sutural line evolutionary complications clearly define the position of the end members of a specific morphogenetic chain. Complexities in the development of the sutural line were a limiting factor in ammonoid evolution by being the main "constriction" of their evolutionary flow. Consider that the wide development of shallow crenulation in the sutural line in ceratites and ammonites, unlikely controlled by the heredity, did not save the ammonoids from complete extinction.

If the ammonoids record the direction of the formation of plastic evolutionary zones based on their sutural lines, then the endocochlians developed in a more radical way by gradual abandonment of their shell. The first endocochlians are represented by the Belemnoidea in the Carboniferous. The Teuthoidea appeared significantly later in the Triassic, followed by the Sepioidea in the Jurassic. These phylogenetic groups in their first stages of the development existed in competition with the dominant ammonoids. A prolonged and slow reduction of the shell did not give endocochlians significant advantages in a competitive struggle with the ammonoids until the end of the Mesozoic. The belemnites, which did not completely abandon formation of a shell disappeared simultaneously with the ammonoids at the end of the Cretaceous.

The competing relationships among the ammonoids captured the more productive nearshore zones of the sea, whereas the belemnites, good swimmers and active predators, inhabited mainly the deeper parts of the shelf, and had a wide area of distribution. The few existing sepiids (cuttlefish) at this time were not considered as strong competitors with other cephalopods. They experienced a burst of adaptive radiation later in the Eocene-Miocene (at the Paleogene and Neogene boundary interval). Subsequently, the sepiids have gone through a stage of idio-adaptation represented by numerous species for which a significant increase of the population density is characteristic. Apparently, in the Paleogene, the sepiids experienced aromorphosis connected with their liberation from a shell. Correspondingly, this process contributed to the increase of their ability to compete intensified their pressure on the nautiloids and other cephalopods. In addition, the teuthoideans, especially the octopods, which also occupied the biological niche of the ammonoids. The first isolated evidence of octopods is reported from the Upper Cretaceous. They apparently exercised a significant destructive influence that contributed to ammonite extinction.

The absence of a shell makes it very difficult to investigate the phylogeny of the octopods. General regularities in the evolution of the cephalopods provide the opportunity to make definite conclusions about the exact replacement of the ammonoids by octopods. By completely eliminating their shell, they achieved a level of development of the nervous system and brain that exceeded many vertebrates (e.g., Fishes). Such a high level of organization gave the octopods an advantage in ability to compete. Octopods possess a rather large brain having 14 lobes. The octopus brain is covered by a rudimentary plate made of tiny grey cells-the control spot of memory. The top the brain is protected by a true carti- 
laginous skull [18]. Octopods possess the ability to manufacture conditioned reflexes such as remembering experiences. Like elephants and dogs, an octopus can distinguish geometrical figures: cross, square, rhomb and triangle. Octopods build shelters from rocks, shells and other seafloor detritus, and can close the entrance to their den with a large rock. In retreat, it can cover its posterior with a rock or hold it in front as a shield. The octopods also possess well developed telereceptors, especially those for vision; no other marine inhabitants have such sharp vision [18].

The progressive physiological developments have had great significance for the phyla of the endocochlians, as well as influencing the evolution of all groups of endoskeletal cephalopods by suppressing their development. The octopods reflect one of the more progressive directions of development within the biosphere by exhibiting the formation of an upper level of evolutionary transformations, which suppresses the progressive development of any group composing the lower layers of the biosphere. Recent endocochliate cephalopods exceed many vertebrate groups in the level of their development, and achieved a level equivalent to some tetrapods in the development of their nervous system and brain.

\subsection{Silurian (Cerebral) Mega-Aromorphosis. Biosphere of Fishes}

Following the Ediacaran-Cambrian mega-aromorphosis, based on morphofunctional transformations of organisms, the Paleozoic super-aromorphosis, is characterized by a radically intensified informative process development of the brain in the evolutionary improvement of various phyla. These changes are clearly displayed only within the framework of the larger phyla, and in significant provisional intervals. Frequent competition between subordinate branches took place within the larger phylogenetic groupings evolving in the direction of passive and active defense. Invariably this competition resulted in the victory for the branch with the more actively improving the nervous system.

The explosion of the Cambrian "skeletal" divergence produced a qualitatively new stage of biospheric evolution. The significant rise in the activity level of organisms is the basis for the sharp increase of the viability of phyla that is determined by a system of adaptations, with the leading role played by improvement of the brain. These evolving phylogenetic groups exerted tremendous pressure upon the other components of the biosphere, many of which lost the opportunity to noticeably raise the level of their own organization. The progressive tendency of biosphere transformation became the way of cerebral development [5] [19]. The pressure from the dominant groups stratified the evolutionary stream of life. Groups that initially adapted, or transitioned, to a sessile mode of life (e.g., radials, bivalves, brachiopods, echinoderms) became the basal stratum. Rapidly evolving, mobile arthropods occupied a higher level of the development, but lagged behind the vertebrates because of exoskeleton limitations. Only the cephalopods, by eliminating their shell, were able to sharply increase their level of organization that exceeded even some vertebrates [20]. 
The pressure of the dominant groups is spread over the lower layers of the evolutionary structure. Competitive pressure from the dominant groups forced others to develop survival strategies at the expense of the lesser developed groups. The competition from the dominant groups is expressed by blocking the development of suppressed groups within the limits of the existing archetype.

The progressive tendencies initiated by the Vendian and Cambrian biota are best observed in the structural design of the fish brain. New archetypes allowed complete exploitation of the bilateral structure, which improved motile activity based on the development of the nervous system, telereceptors and the brain. Competition became intense between the actinopterygians, with everting development of ventricle closure in the brain, and sarcopterygians, with inverted development [21].

The jawless agnathans, the most ancient vertebrates, have a small, primitive brain, and archaic circulatory and digestive systems. Organs of movement are represented by a vertical caudal fin of various configurations. Dorsal and anal fins sometimes developed from other fins, but paired fins, important for active maneuvering are very rarely present. Jawless vertebrates were passive filterfeeders. Lampreys, recent representatives of this group, exhibit primitive development because of their semi-parasitic life style. Possession of an endoskeleton is characteristic of most Paleozoic agnathans, demonstrating retrogradational development from a passive life style. The absence of a jaw apparatus and poor mobility significantly limited agnathan success.

The features of the new fish archetypes permitted full exploitation of the bilateral structure potential as mobile activity improved with the development of the brain. This system improved both mobile activity, and the development of a central nervous system: movements that require brain development; an improved brain function promotes new possibilities for complicated movements.

Thus, jawless vertebrates are still well below the limit of the aromorphosis. A jaw apparatus, which not only significantly expands the abilities of the organism to influence the environment, but activates the development of the brain, was an indispensable element of the new aromorphic archetypes. The development of a perfect mobile apparatus, which would provide narrow, precise and fast spatial maneuverability, is also an indispensable element of the aromorphic structure. Fish possess mobile adaptation through the use of fins.

The appearance of a new aromorphic advanced group of fish exhibits a burst of radiation of forms covered by an external carapace. Phylogenetic branches, which evolved toward passive forms of defense, are characteristic of the first stages of evolution for new groups. Such a method of development provides quick and effective initial results. Placoderms appeared at the end of the Silurian, and characterize populations throughout the entire Devonian. Associated acanthodians also exhibited active development, but were no better developed, and therefore, did not form a strong competitive group. Loricates appeared in the middle of the Silurian and continued to coexist with placoderms in the Devo- 
nian.

The appearance of the cartilaginous fish at the end of the Devonian ended the reign of the placoderm vertebrates. The placoderms are virtually absent in Carboniferous strata. The cartilaginous fish had an internal skeleton that did not block the evolution of the group toward a better means of active defense. They were good swimmers with an elongate streamlined body and active predators with a well-developed brain and sensory organs. Typical cartilaginous fish, the sharks, are widely distributed modern representatives of this assemblage.

Further development of fish was in the direction of the improvement of the internal skeleton, which promotes evolutionary plasticity, development of mobile activity and a general improvement of their organization. The Osteichthyes, bony fish, are the most numerous and wide spread vertebrate group in modern seas, consisting of more than 25 thousand species [22] [23]. They have developed various biotopes in marine and fresh water basins at all depths. Furthermore, the development of quite fanciful forms, for example, the sea horses (Syngnathiformes), or Lophius, the deep fish-angler (Lophiiformes), are bony fish, even though most are harmonically organized good swimmers [22] [23]. However, bony fish have not achieved new heights in the evolutionary development since their appearance. According to Severtsov, this development is typical of improvements reached earlier by aromorphic adaptation at the level of idio-adaptations [1].

\section{Conclusions}

The evolution of living organisms can be understood only by considering the composition of the biosphere as a complete entity. The development of life occurs within a framework of the universal interaction, and mutual dependence of all components of the biosphere. The great qualitative progress, which is the result of the evolution of all living organisms, protozoans to humans, has been driven through time by competition among the individuals that comprise the various phylogenetic groups and biocoenoses. Adaptations ensuring the maximum development of both organisms and biosystems can be the direct or indirect result of their competitive, interactive struggle through time.

The lowest level of the evolutionary system-the species-is the motor for biological forms. In a species, reproduction induces natural selection that leads potentially to an evolutionary shift to its archetype. The result of microevolution serves as the original basis for macroevolution, in which archetypes with successful evolutionary changes are selected.

The evolution of the biosphere is identified by its main components-the largest and most successful, long living phyla reflect a successful archetype, with the dominant vertebrate groups playing a leading role. The general features of the structure of the archetypes of large groups determine the evolutionary potential and direction for the development of their subordinate branches. In macroevolution that proceeds over long intervals of time, the higher taxonomic groups are 
far more successful entities than species.

In the process of the evolution of the main phyla, negative competitive relationships between subordinate branches through various adaptations are transformed into positive relationships (different views of what constitutes food and development of symbioses) that are converted into biocoenosic, and additional biospheric connections.

The structure of the evolutionary transformation of the biosphere is determined by the successive change of genetically related groups that developed along the path of unrestricted progress-the dominant groups. The general development of dominant groups is expressed by an increase of organization of a separate organism-individual.

The stages of the development of dominant groups do not necessarily reflect their stages of their development. If the appearance of a new dominant group is determined by completion of the formation of the main characters of its archetype, then the beginning of a new stage of the evolution of the biosphere is connected with adaptive radiation of the dominant group. At that time, the subordinate groups passed through rigid intragroup selection that forced out and suppressed phyla belonging to representatives of a previously dominant group. General biospheric reconstructions experienced a delay of between 10 - 20 my. A prolonged period of "maturing" (endoprotomorphosis) of a new archetype within a previously dominant group precedes the appearance of a new dominant group. The establishment of superiority in groups that evolve in the direction of unlimited progress contributes to the evolutionary transformation of the biosphere.

\section{Authors Note}

Professor A. V. Popov is an internationally known paleontologist, and for many years Chairman of the Paleontology Department, St. Petersburg State University, Russia. He published numerous scientific papers over his career that spanned more than half a century, but all were in the Russian language. This paper, part 1 of An Evolutionary Model for the Neoproterozoic (Ediacaran)-Phanerozoic Biosphere, represents the culmination of his thoughts on the procession of life through geologic time, and his first paper in English. His co-authors are pleased to have played a small role in translating and editing this paper for dissemination to Dr. Popov's friends, colleagues and other students of the biosphere.

\section{References}

[1] Severtsov, A.N. (1949) Morphologicheskie zakonomernosti evolyutsii [Morphological Regularities of the Evolution]. Leningrad, Moskva, 536 p. (In Russian)

[2] Vernadsky, V.I. (1975) Razmyshleniya naturalista. Prostranstvo i vremya v nezhivoy i zhivoy prirode. [Reflections of a Naturalist. Space and Time in the Animate and Inanimate Nature.] Izdatelstvo "Nauka", Moskva, 176 p. (In Russian)

[3] Darwin, C. (1859) The Origin of Species. Castle Books, a Division of BOOK SALES, INC. Open Library, Internet Archive, 703 p. 
[4] Popov, A.V. (1978) Ob etapnosti evolyutsionnogo razvitiya organizmov. [On Stages of the Evolutionary Development of Organisms.] Trudy XVIII sessii VPO, Leningrad, 22-30. (In Russian)

[5] Popov, A.V. (1993) Filogenez i evolyutsiya biosfery. Filogeneticheskie aspekty paleontologii. [Phylogeny and Evolution of the Biosphere. Phylogenetic Aspects of Paleontology.] Trudy 35 sessii VPO, Izdatel'stvo Nauka, St. Petersburg, 7-16. (In Russian)

[6] Popov, A.V. (2006) Evolyutsiya kak camorazvivayushchayacya sistema. [Evolution as Self-Developing System.] Publishing House of St. Petersburg State University, St. Petersburg, 152 p. (In Russian)

[7] Popov, A.V. (2011) O smene paradigm evolyutsionnoy teorii. [About Change of the Paradigm of the Evolutionary Theory.] V: Nesterov, E.M., Ed., Geologiya, geoekologiya, evolyutsionnaya geografiya [In: Nesterov, E.M., Ed., Geology, Geoecology, Evolutionary Geography], Sbornik nauchnykh trudov po materialam 11 mezhdunarodnogo seminara. Izdatel'stvo RPGU imeni A. I. Gertsena, St. Petersburg, 15-21. (In Russian)

[8] Popov, A.V. (2008) Evolyutsiya i sistematika. [Evolution and Systematics.] Materialy 54 sessii of VPO, St. Petersburg, 146-149. (In Russian)

[9] Dogel, V.A. (1981) Zoologiya bespozvonochnykh: uchebnik dlya universitetov. [Zoology of Invertebrates. Textbook for the Universities.] Polyanskiy, Yu. I. (ed.), 7th Edition, Vysshaya shkola, Moscow, 606 p. (In Russian)

[10] Mikhaylova, I.A., Bondarenko, O.B. and Obrucheva, O.P. (1989) Obshchaya paleontologiya. Uchebnik. [General Paleontology. Textbook.] Izdatel'stvo Moskovskogo Universiteta, Moskva, 384 p. (In Russian)

[11] Drushchits, V.V. (1974) Paleontologiya bespozvonochnykh. Uchebnik [Paleontology of Invertebrates. Textbook]. Izdatel'stvo Moskovskogo Universiteta, Moskva, 528 p. (In Russian)

[12] Lamsdell, J.C., Briggs, D.E.G., Liu, H., Witzke, B.J. and McKay, R.M. (2015) The Oldest Described Eurypterid: A Giant Middle Ordovician (Darriwilian) Megalograptid from the Winneshiek Lagerstätte of Iowa. BMC Evolutionary Biology, 15, 169. https://doi.org/10.1186/s12862-015-0443-9

[13] Braddy, S.J., Poschmann, M. and Tetlie, O.E. (2007) Giant Claw Reveals the Largest Ever Arthropod. Biology Letters, 4, 106-109. https://doi.org/10.1098/rsbl.2007.0491

[14] Westheide, W. and Rieger, R. (2008) Zoology of Invertebrates in Two Volumes. Tovarishschestvo nauchnykh izdaniy KMK, Moscow, 935 p.

[15] Beklemishev, V.N. (1964) Osnovy sravnitelnoy anatomii bespozvonochnykh. Izdatel'stvo Nauka (v dvukh tomakh), Moskva, Vol. 1, 432 p, Vol. 2, 446 p. (In Russian)

[16] Shimansky, B.N. (1962) Nadotryad Nautiloidei. Obshchaya chast'. Klass Golovanogii. Obshchaya kharakteristica. Ocnovy paleontologii. [Superorder Nautiloidea. General Part. Class Cephalopoda. General Characteristics. Basics of Paleontology]. Izdatel'stvo Akademii Nauk, Moskva, 15-72.

[17] Popov, A.V. (1987) Evolyutsionnoe znachenie lopastnoy linii ammonoidey [Evolutionary Significance of Sutural Line of Ammonoids]. Ezhegodnik VPO, 30, 162-176. (In Russian)

[18] Akimushkin, I.I. (1968) Klass golovonogie (Cephalopoda). Zhizn' zhivotnykh. V 6 tomakh. Tom 2. Bespozvonochnye. [Class Cephalopoda. Life of Animals. In 6 Volumes. Vol. 2. Invertebrates]. Izdatel'stvo Prosveshchenie, Moskva, 156-197. (In Russian) 
[19] Popov, A.V. (2009) O zakohomernostyakh razvitiya phanerozoyskoy biosphery [About Peculiarities of the Development of the Phanerozoic biosphere]. Vestnik St. Petersburg State University, seriya 7, Geologiya, geographiya, vyp. Vol. 3, 21-34. (In Russian)

[20] Popov, A.V. (2012) Tsefalopody osobennocti i perspektivy evolyutsii [Cephalopoda Peculiarities and Perspectives of the Evolution]. V: Sovremennye Problem izucheniya golovonogikh mollyuskov. Morfologiya, sistematika, evolyutsiya i biostratigrafiya [In: Recent Problems of the Studying of Cephalopodal Mollusks. Morphology, Systematic, Evolution and Biostratigraphy]. PIN RAN, Moscow, 40-41. (In Russian)

[21] Obukhov, D.K. (1999) Evolyutsionnaya morfologiya konechnogo mozga pozvonochnykh [Evolutionary Morphology of the Vertebrate Telencephalon]. Izdatel'stvo St. Petersburg State University, St. Petersburg, 203 p. (In Russian)

[22] Romer, A.S. and Parsons, T.S. (1992) Anatomiya pozvonochnykh. V 2-x tomakh (t. 1, 358 p, t. 2, 406 p) [Translation in Russian by Kuznetsov, A.N. and Sidorova, T.B. from Romer, A.S. and Parsons, T.S., 1986. The Vertebrate Body. Saunders College Publishing, 656 p].

[23] Carroll, R.L. (1993) Paleontologiya i evolyutsiya pozvonochnykh: v 3-x tomakh. Tom 3. Moscow, Izdatel'stvo Mir, t. 3, 312 p. [Translation in Russian by Belov, V.V. and Karkhu, A.A. from Carroll, R.L., 1988. Vertebrate Paleontology and Evolution. W. N. Freeman and Company, New York, 698 p].

\section{Scientific Research Publishing}

\section{Submit or recommend next manuscript to SCIRP and we will provide best service for you:}

Accepting pre-submission inquiries through Email, Facebook, LinkedIn, Twitter, etc. A wide selection of journals (inclusive of 9 subjects, more than 200 journals)

Providing 24-hour high-quality service

User-friendly online submission system

Fair and swift peer-review system

Efficient typesetting and proofreading procedure

Display of the result of downloads and visits, as well as the number of cited articles

Maximum dissemination of your research work

Submit your manuscript at: http://papersubmission.scirp.org/

Or contact ojg@scirp.org 